\title{
MINING INDUCED SEISMIC EVENTS AND SURFACE DEFORMATIONS MONITORED BY GPS PERMANENT STATIONS
}

\author{
Zbigniew SZCZERBOWSKI * and Janusz JURA \\ AGH University of Science and Technology, Faculty of Mining Surveying and Environmental Engineering, Department of Mining Areas \\ Protection, Geoinformatics and Mining Surveying, al. A. Mickiewicza 30, 30-059 Kraków, Poland \\ *Corresponding author's e-mail: szczerbo@agh.edu.pl; jura@agh.edu.pl
}

\section{ARTICLE INFO}

Article history:

Received 15 January 2015

Accepted 20 May 2015

Available online 13 July 2015

Keywords:

Mine surveying

Mining tremors

Permanent GPS/GNSS observation

\begin{abstract}
GPS/GNSS surveys carried out by the reference stations of national or local networks also provide a new type of data for geodynamic investigations. On the basis of continuous-time or GNSS position time series with high sample rates it is possible to determine the mobility of large areas. Such mobility can be a result of both natural (such as tectonic) or anthropogenic effects (such as mining).

Results from the GPS/GNSS permanent stations of Legnica-Głogów Copper District (LGCD) from the starting points in time of mining tremors are discussed here. The spatial-temporal evolution of the surface vertical displacement of these areas demonstrated relations with seismic tremors or rock burst induced by mining. We discuss changes in displacement parameters in the time period when seismic events occurred. According to the authors temporal and spatial characteristics and distributions are not accidental, which means that the coordinates of some permanent GNSS stations working within the Polish Active Geodetic Network (ASG-EUPOS) and about $40 \mathrm{~km}$ distant could be affected by tremors. The most interesting is the subsidence basin which is formed after mining tremors with the center located near the area of epicenter and with maximal vertical displacements about $10 \mathrm{~mm}$. This far-reaching deformation effect can be explained only by the influence of the tectonic setting of the area. However, the authors are cautious about their conclusions, suggesting more studies on the problem initially presented in the paper.
\end{abstract}

\section{INTRODUCTION}

The study of mining tremors or rock fracture is a subject of widespread interest, with relevance mostly to the safety of underground works. The released energy can destroy mine workings, lead to the violent fracture of the rock surrounding mining excavations, reduce the potential energy of the rock and finally induce the rock mass to reach a different equilibrium state. Mining induce tremor hazards in LGCD is a problem for nearby urban areas.

It is important to be able to predict as far as possible the time, location and intensity of potential mining tremors. The modeling of rock fracture, rock burst or mining tremors is one of the most important areas of study. Seismic measurements are usually a practical tool for the verification of stress models, which provide a physical outline of this phenomenon. Geodetic measurements yield strain data important for the anticipation of natural earthquakes (e.g. Feigl, 2002; Crowell et al., 2012; Melgar et al., 2012). The future study of the precursor of earthquakes lies in joint geophysical and geodetic research. The increasing number of papers concerned with geodetic surveys in earthquake studies shows the importance of geodesy in earthquake physics. Geodetic studies in this area provide such significant benefits as monitoring the effects of earthquakes, including postseismic relaxation, estimating the structural deformations of large engineering structures, compiling data from a variety of sources for GIS, to be used by civil engineers (e.g. Feigl, 2002; Crowell et al., 2012; Melgar et al., 2012).

The above remarks concern the monitoring of natural, not mining shocks. Studies on mining tremors are still inadequate. Only few papers deal with the problem of the effects of mining tremors as observed by geodetic measurements (Wanior, 1983; Popiołek et al., 2001; Hejmanowski et al., 2008). The authors discuss mainly the problem of the observed subsidence of control points in areas of tremor epicenters. Long experience in deformation measurements in Polish mining provided interesting results on the problem of tremors and rock burst. According to J. Wanior (1983) the phenomena is preceded by abnormal displacements (differing from those which form subsidence basins caused by extracted strata). The values of uplifts preceding mining tremors and detected by spirit leveling underground were proportional to the energy of the tremors or rock bursts, which occurred afterwards.

Although, when a rock mass is penetrated by mining, it is usually quite well recognized what makes stress modeling more reliable, its geomechanical properties and stress field change under the influence of excavation works. The geological setting (rock types, their bedding, faults) plays a crucial role in the 
mechanism of mining tremors and the relaxation of the stress field in a rock mass. Thus as far there are no significant studies which combine geophysical and geodetic research in the modeling of the deformation of a rock mass induced by mining tremors. The few geodetic studies (Popiołek et al., 2001; Hejmanowski et al., 2008), which there are on this topic are based on insufficient geodetic data (the number of points, spatial distribution, frequency of measurements etc.), so they can be considered only as initial ones although promising in the study of the precursors of mining tremors.

This paper shows a further stage in research into mining tremors, where the temporal and spatial distributions of displacements are examined. Changes in the coordinates of permanent GPS/GNSS stations are discussed in the text. They occurred during events of mining tremors caused by the Rudna mine located in the LGCD area and two events are analyzed in the paper.

\section{GEOLOGICAL SETTING AND MINING CONDITIONS}

Building on modern concepts based on observations of the energy release from seismic events and the seismic pattern of mining areas with large and destructive mining tremors, there is often a superimposition of mining stress onto a preexisting stress field. Seismic events strictly associated with mining activity are sometimes caused by shear failures on existing faults or other mechanically weak geological structures. This association of larger mining tremors with preexisting geological features has been reported by many investigators (e.g. Swanson and Sines, 1991; Kijko and Cichowicz, 2006). So, the geological and especially the tectonic setting is essential in understanding this problem in terms of not only ongoing phenomena but also the general seismic mechanism itself. This interaction of two stress fields, tectonic and mining induced (lower seismic energy) what is known as "a complex event" (Kijko and Cichowicz, 2006).

There has been some research works on this problem, and in particular, devoted to the area of the Legnica-Głogów Copper District (LGCD), widely discussed in (Węglarczyk and Lasocki, 2009; OrleckaSikora et al., 2009; Butra and Kudełko, 2011). The brief description presented here concerns what is relevant to this article.

The studied area is located in south-western Poland and its size is approximately 600 square $\mathrm{km}$. It is part of the Sudety Foreland and contains the main cities of the region Lower Silesia Province, Lubin, Głogów and Polkowice.

The LGCD region houses the copper ore deposit mined by KGHM, a mining company which owns underground copper ore mines of Lubin, PolkowiceSieroszowice and Rudna. These mines are on the same large cooper ore deposit and they are adjacent to each other.
The basic geological structure of the area of LGCD is one of a gently-dipping complex of rock strata with copper ore deposits. It is part of the ForeSudetic Monocline (Fig. 1). Its crystalline basement comprises Cambrian, Silurian and Carboniferous deposits represented in general by metamorphosed (weakly) sandstones, arkoses and shale, strongly metamorphosed schists, volcanic rhyolites and diabases and basalts (Oberc and Tomaszewski, 1963; Kłapciński, 1964; Preidl, 1968; Kucha, 1998).

Overlying sedimentary rocks commencing with Zechstein sandstones belong to the Permian and Triassic eras and they dip at an angle of a few degrees usually in NE direction (Fig. 1). The Permian-Triassic formations of the monocline demonstrate variable thicknesses (from 0.4 to about $20 \mathrm{~m}$ ) and a varying lithological profile (sandstones, dolomites and shales). They are discordantly overlain with Tertiary and Quaternary sediments - clay, sands, gravel and brown coal (Tertiary). The cooper ore deposit series are associated with formations of the Upper Permian (Zechstein) dip to the NE (Fig. 1), in accord with the strata forming the monocline, so the deposit is classified as a stratified ore deposit. A remarkable geomechanical property of these rock strata series is their contrast in strength; the suite of dolomites and anhydrites overlying the deposit has strengths ten times higher than the underlying sandstones (Salski, 1996; Butra and Kudełko, 2011). The rocks of the ore deposit and the surrounding rocks have a natural potential to accumulate elastic energy and the tendency to release this accumulated energy. Another factor conditioning mining tremors is the tectonic frame of the area, especially a number of discontinuous dislocations within the deposits (Butra and Kudełko, 2011). Faults are mostly NW-SE oriented and deviations are in the NWW-SEE or NNW-SSE direction (Fig. 2). The structural pattern is based on the main faults or fault zones as follows: the main Lubin fault, the Sobin fault, the Szklary Górne fault, the Polkowice fault, the Central Rudna fault, the Sieroszowice and the Biedrzychow fault. These main dislocations and other, second order discontinuities, make a system of numerous block structures and finally create the fault-block structure of the geology of the area (Salski, 1996). The geodetic observations presented below concern the area of the Rudna mine, known as the most affected by mining tremors. The local geology is characterized by the main fault zones there (Fig. 2):

(a) the "Biedrzychowa" fault zone occurring in the south-eastern part of the area with a direction close to W-E,

(b) the "Central Rudna", a zone with NW-SE faults in the southern part of the deposit area. The zone comprises a group of faults forming horsts and grabens with amplitudes from several to 30 meters. This area is particularly affected by tremors and rock bursts, 

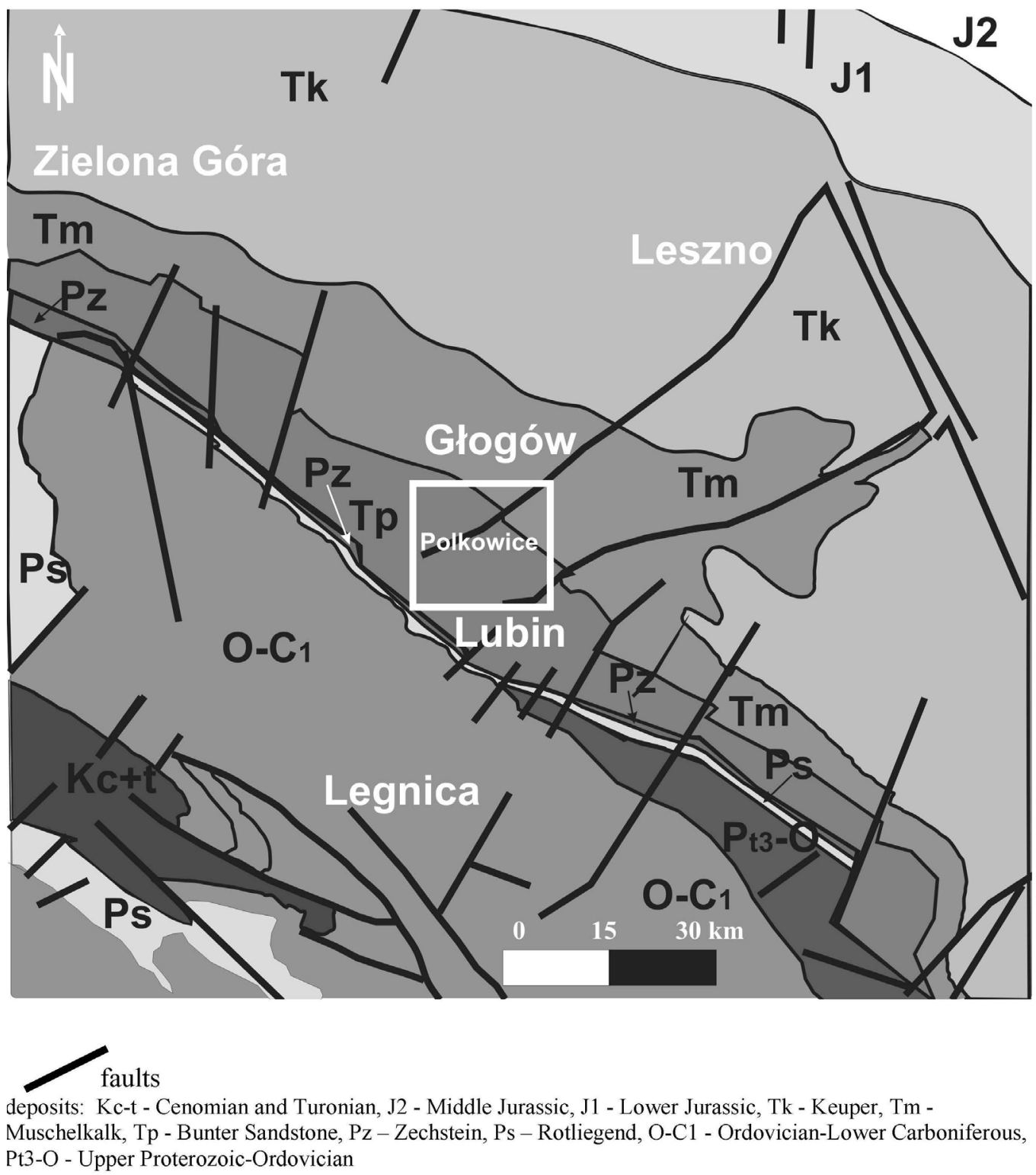

Fig. 1 Simplified geological setting of the studied area (according to Dadlez et al., 2000) and location of mining area of the discussed tremors (marked).

(c) the "Trzebcz-Polkowice" fault zone in the northwestern part of the area with a direction close to W-E.

\section{SURVEY DATA}

Although there are many studies dealing with geodetic measurements for identifying developing rock mass instabilities and geodetic quantitative characterizations of the effects of seismic events in earthquake affected areas, they usually don't examine mining tremors and rock bursts (Feigl, 2002; Crowell, 2012; Melgar, 2012). This could lead to the false conclusion that the lower energy of tremors and rock burst induced by mining leads to damage caused only by shocks and no steady displacements of the terrain surface.
The starting point for further analysis are data about displacements induced by mining tremors in the LGCD area. The displacements were evaluated from changes in permanent stations coordinates.

Fulfilling requirements for the estimation of terrain surface deformation and the risk to structures there is rigorous geodetic monitoring of the area. This involves both classical (leveling etc.) and GPS/GNSS observations of control points distributed over the large area of LGCD. The deformation process affects urbanized areas and it varies spatially and temporally. Some details about geodetic measurements in the studied area can be found in articles (Popiołek et al., 2001; Hejmanowski et al., 2008). The authors discuss the impact of rock burst in the displacement process of the control points which are involved in regular 


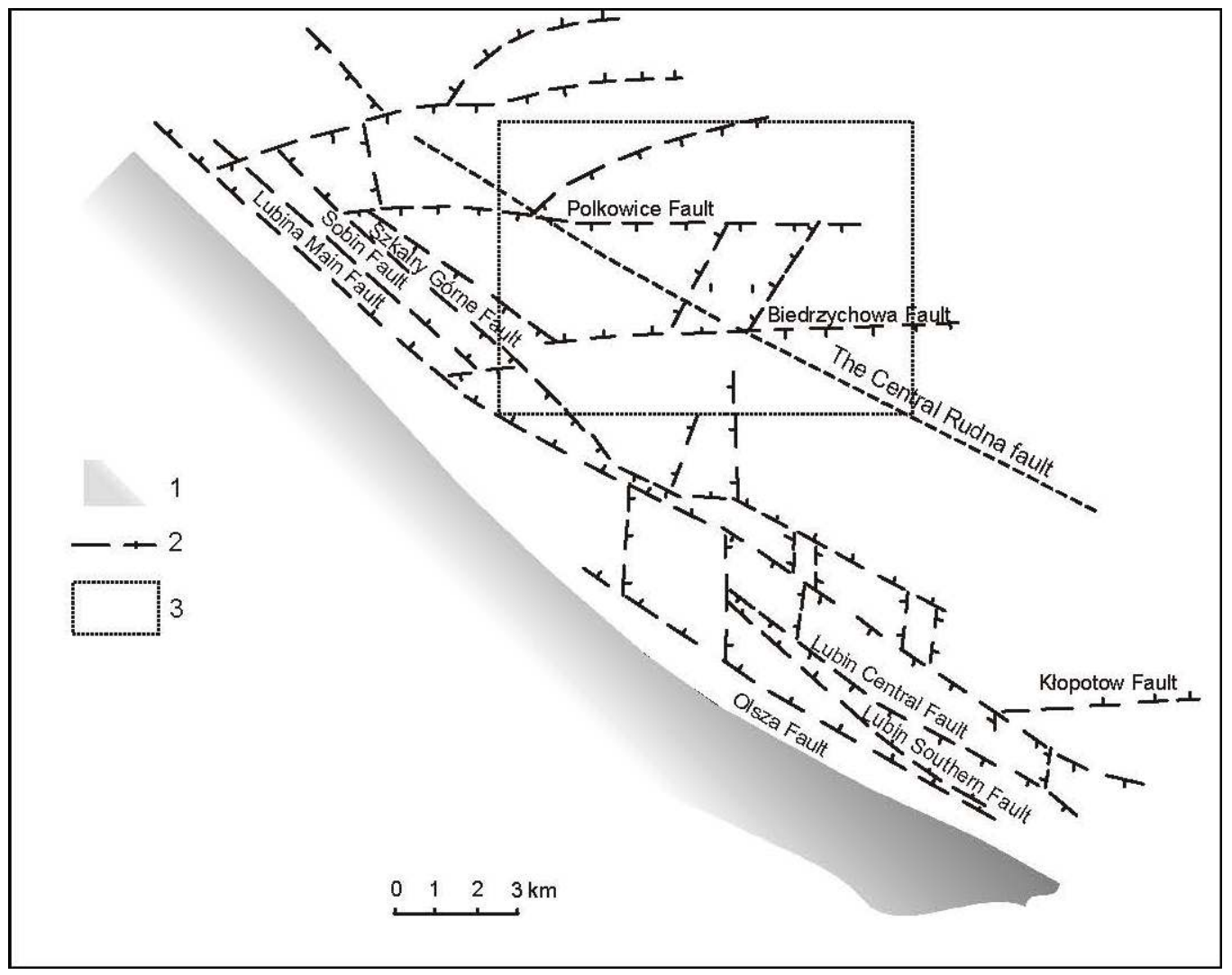

Fig. 2 Scheme of fault lines in the area of LGCD (according to Salski, 1996).

1. presudetic block with metamorphic rocks, 2. fault lines 3. the area of discussed tremors

geodetic monitoring. There were some disturbances in the special distribution of the subsidence process of the points as a probable result of rock burst and tremors which occurred in the Rudna and the Lubin mines. One seismic event and its effects in the process reported by Popiołek et al. (2001) occurred on April 11, 2000. After a mining tremor of energy $2.5 \times 10^{9} \mathrm{~J}$, an increase in terrain surface subsidence was observed with a value of $0.119 \mathrm{~m}$ being registered. The estimated maximal value based on the spatial distribution of subsidence over the epicenter was, according to the authors, as high as $0.140 \mathrm{~m}$. The observed effect of the subsidence was a concentric system of displacement isolines with a radius of about $900 \mathrm{~m}$, whose the centre was located approximately over the tremor epicenter, which was determined by on analysis based on data from the seismic station (Popiołek et al., 2001).

More seismic events, which occurred in the Rudna mine and affected the process of subsidence were discussed by Hejmanowski et al. (2008). According to these authors no horizontal displacements induced by mining tremors were observed. Their results suggest accidental vertical displacements caused by two mining tremors, one of $10^{8} \mathrm{~J}$ in 2004 and another $10^{9} \mathrm{~J}$ in 2006, which occurred in the Rudna mine. According to observed fluctuations in the vertical displacements, the values of subsidence induced by tremors amounted to $0.06 \mathrm{~m}$ (Hejmanowski et al., 2008). Comparing the displacement effects, which occurred during various seismic events, it can be presumed that the above values correspond to the size of energy released by the tremors. However, these effects of mining tremors are described using GPS/GNSS observations, and the results are restricted to displacements of single points in a small area. They still leave therefore questions about the role of the geological and tectonic background and which would provide essential inputs into any dynamic model of the changes. These are topics dealt with modern geodesy in earthquake affected areas. Strong mining tremors with an energy over $10^{6} \mathrm{~J}$ occur dozens of times a year in the area (Orlecka-Sikora et al., 2009), but the effects have not usually been investigated by geodetic methods or there isn't enough geodetic data providing information about displacements caused only by tremors.

The effects of two strong tremors are analyzed in this paper. They were selected as ones whose effects were felt so far away (over $30 \mathrm{~km}$ ), that they were remarked upon press releases. The effects were analyzed in terms of their impact on dynamic regional phenomena in the form of surface terrain displacements and the analysis was based on the example of two tremors which occurred in the Rudna mine (Fig. 3).

On March 19, 2013 at 22:09 local time, a seismic station in the Rudna mine recorded a very strong tremor with a calculated energy of $1.6 \times 10^{8} \mathrm{~J}$. It was 


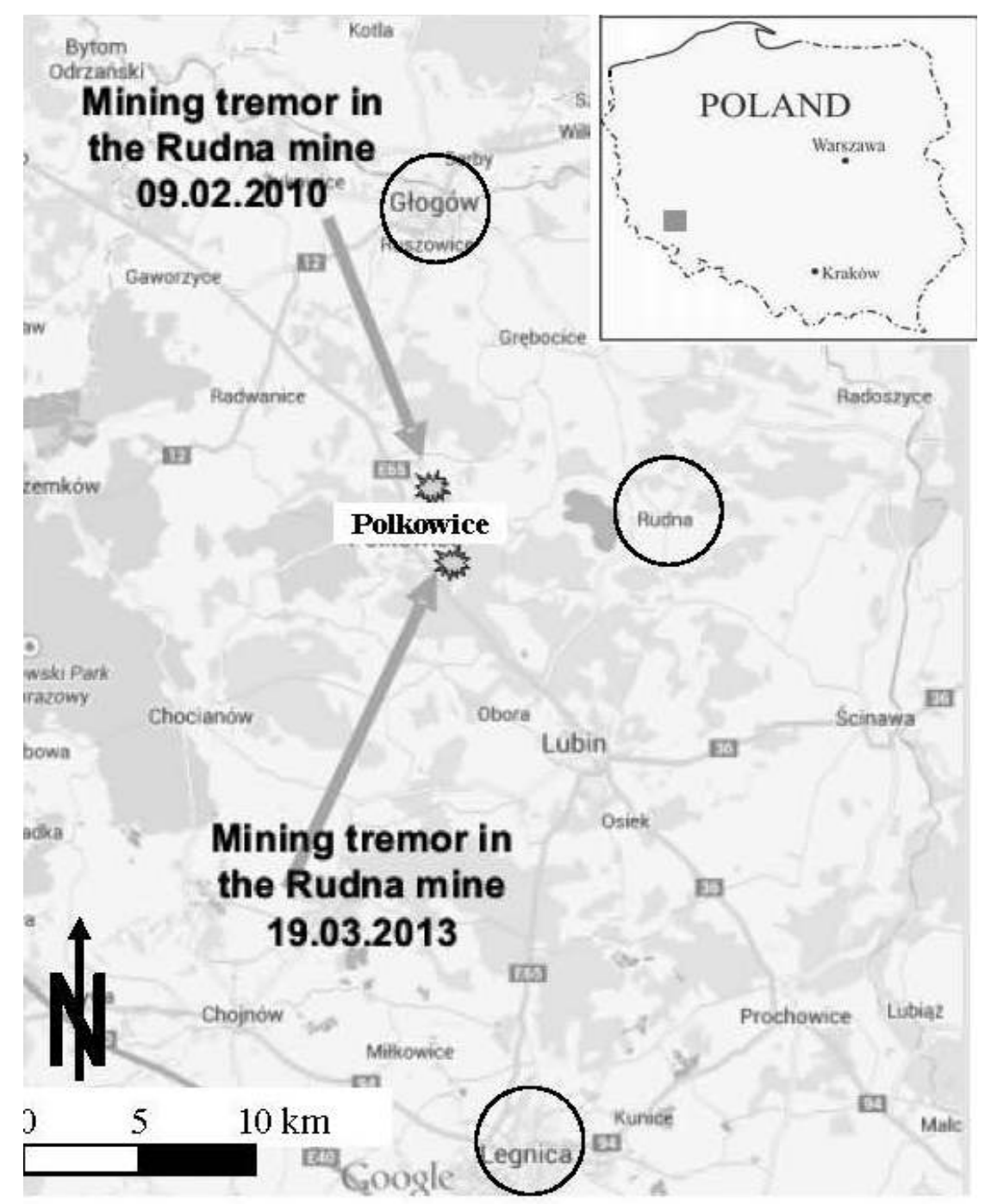

Fig. 3 Localizations of analyzed permanent stations and epicenters of analyzed tremors in the area of Polkowice (base map from Google Maps, Dec. 2014).

classified as one of the strongest to have occurred in Polish copper mining (Lizurek et al., 2014). The epicenter of the tremor was close to the Rudna Central fault. The tremor was also registered by distant seismic stations and caused widespread effects within the mine. According to the judgment of a special commission to investigate the causes and circumstances of the event, it happened in a zone with specific characteristics and was caused by the dynamic activation of the above mentioned fault, associated with the displacement of rock layers over a large fault plane area (see: http://www.wug.gov.pl/index.php?statystyki/19 $03 \quad 2013$;

Laskowski et al., 2014). Another seismic event occurred on 9 February 2010, at 15:26 local time, with an epicenter located in the Rudna mine. This geological zone is classified as being prone to rock burst and this phenomenon was classified as rock burst according to the commission appointed by the Mining Authority (see: http://www.wug.gov.pl/index.php?statystyki/9 02 2010).
Given the above facts about the local effect of mining tremors there is the question of how the seismic events affected the positions of the permanent stations working in the LGCD area. There are two stations about $40 \mathrm{~km}$ away from the Rudna mine: Głogów in the northwest and Legnica in the south (Fig. 3). They are GNSS stations working in ASG-EUPOS, a national multifunctional system for precise satellite positioning (The Polish Active Geodetic Network ASG-EUPOS). ASG-EUPOS started to operate in 2008 providing data from about 130 permanent GNSS stations located in Poland and in neighboring countries in areas adjacent to Poland's border and since then there has been scientific progress in geodynamics. The sufficiently long period of observations gives a basis for making attempts to model some processes derived from the displacements monitored by ASG-EUPOS. Although there are a lot of papers devoted to geodynamics in the whole of Poland (Bogusz et al., 2012), most regional investigation has dealt with the south-western part of 


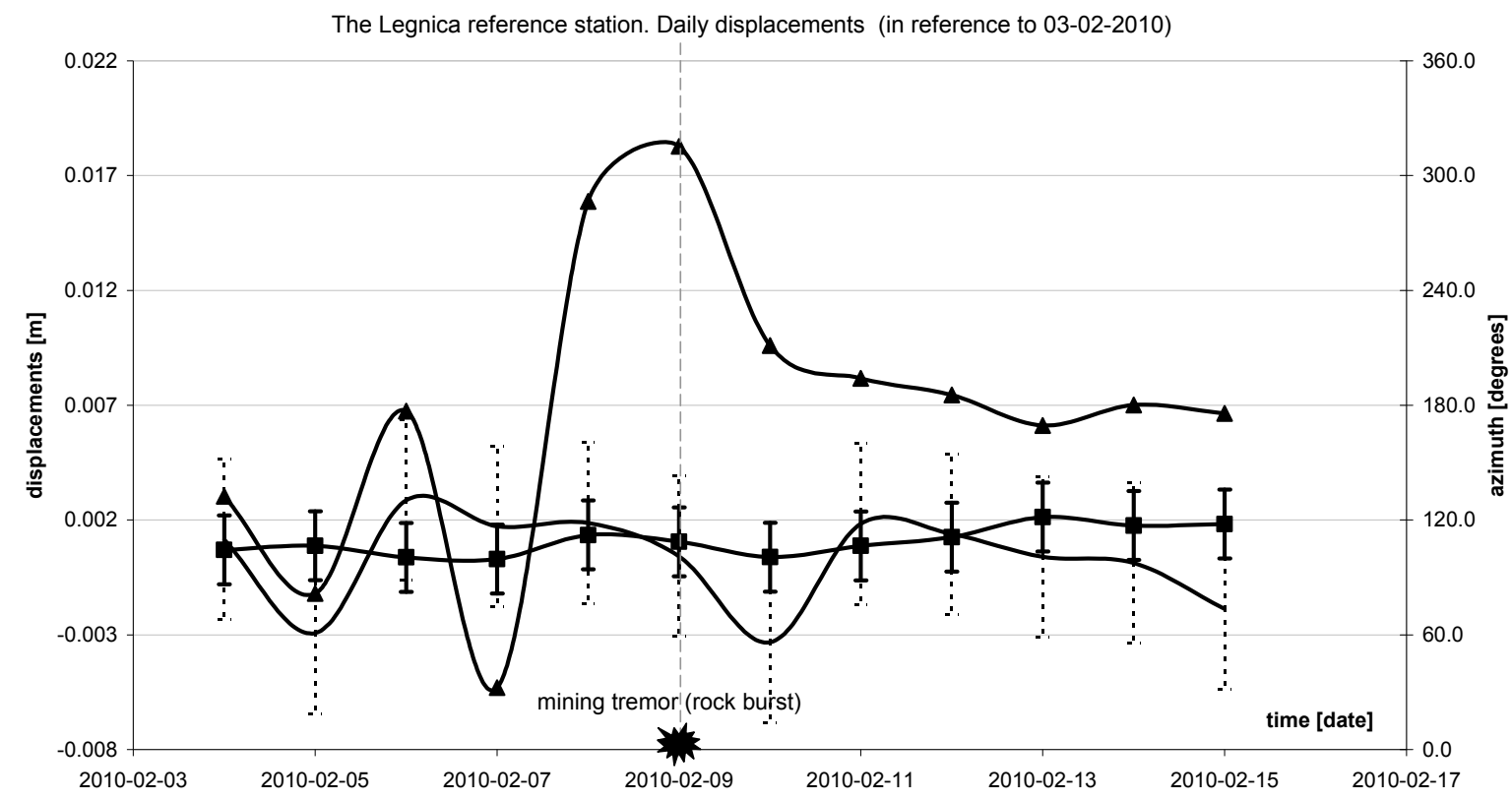

$\longrightarrow$ vertical displacement $\rightarrow$-horozintal displacement $\rightarrow-$ azimuth of horizontal displacement vector

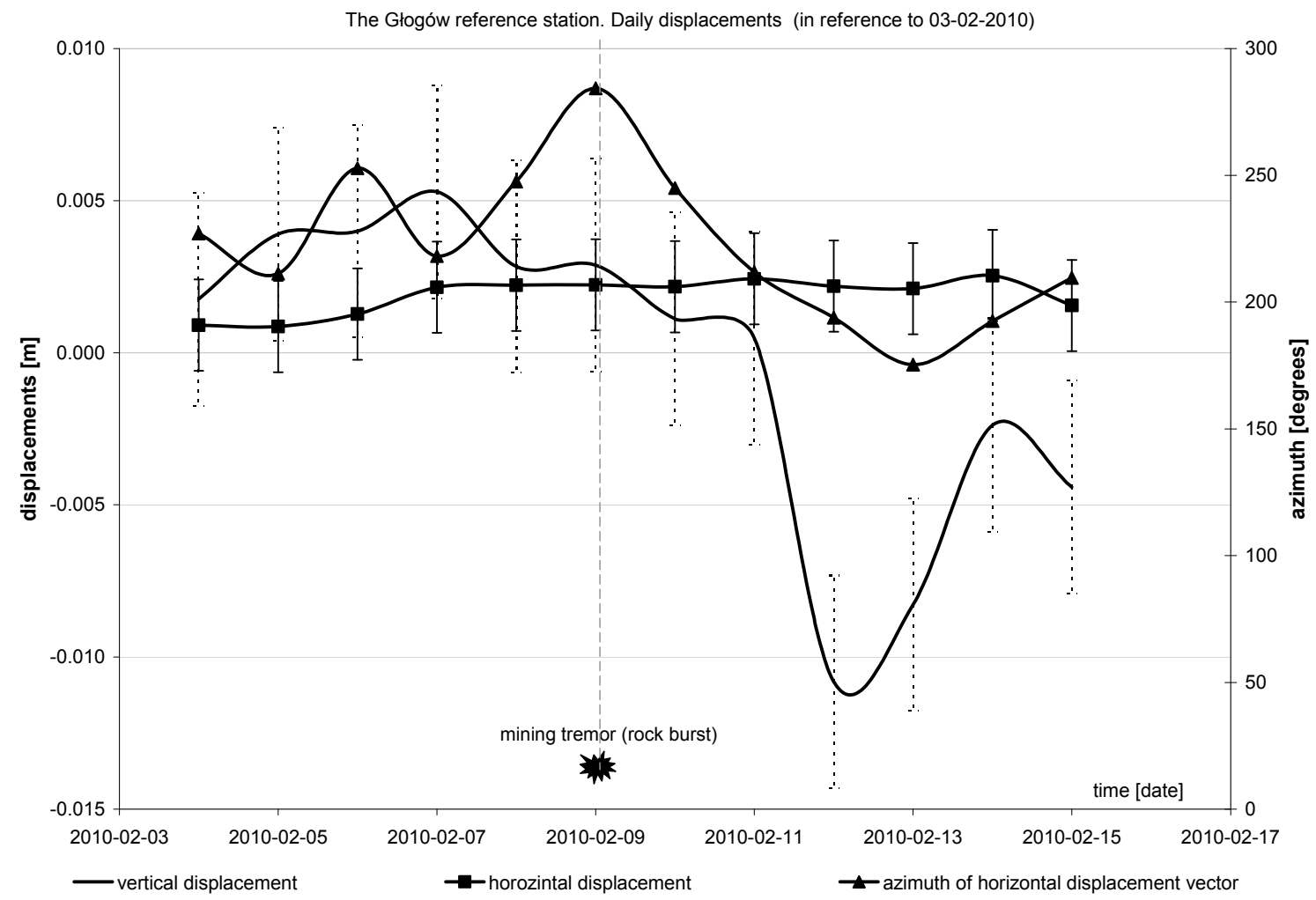

Fig. 4 Vertical displacements and horizontal displacements with the error bars and azimuth of displacement vectors of the analyzed permanent stations, February 2010. 


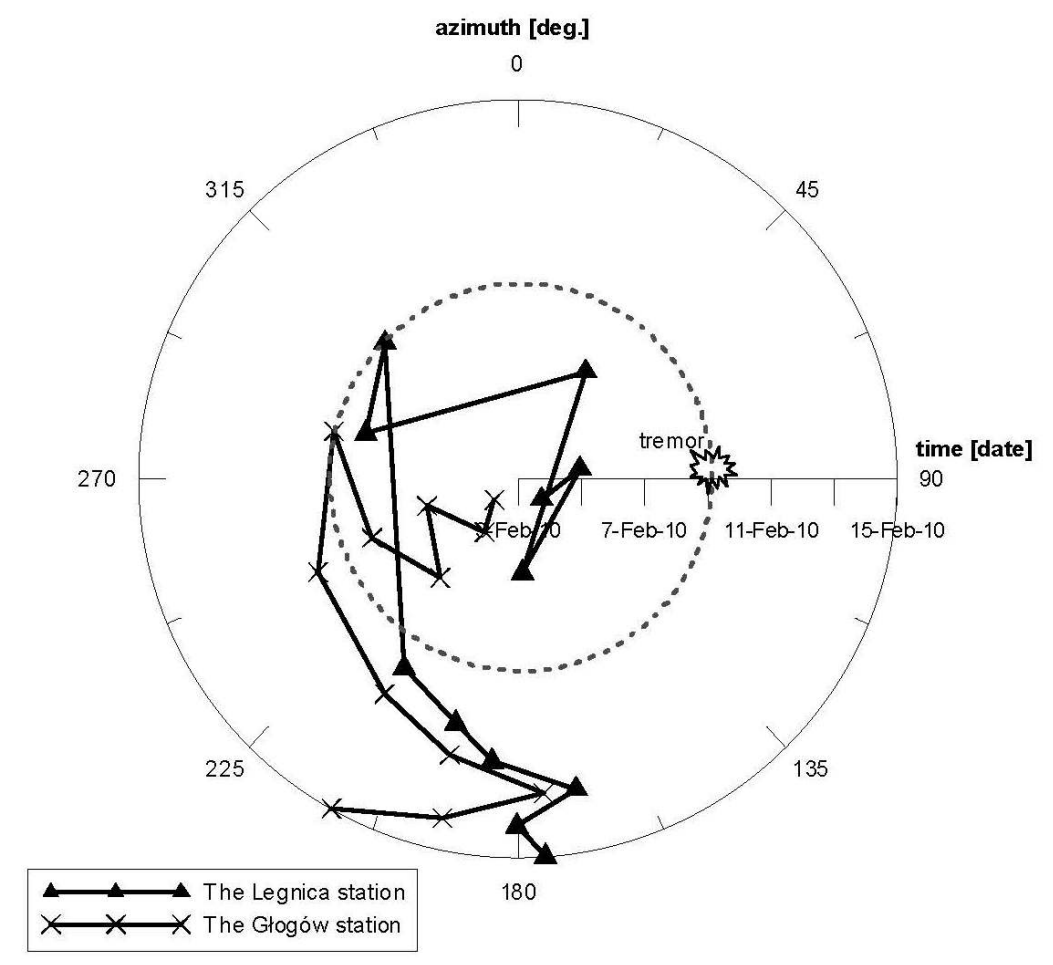

Fig. 5 The Głogów and the Legnica stations. Changes of azimuth of displacement vectors in February 2010.

Poland (Kontny and Bogusz, 2012) indicating tectonically active area where the ASG-EUPOS stations are located. This analysis is based on coordinates evaluated in ASG-EUPOS system as daily outcomes (solutions). According to the system's general standards the accuracy of daily results is on average about $2 \mathrm{~mm}$ for each horizontal and $4 \mathrm{~mm}$ for vertical coordinates. However, this average error term can be stated more precisely for data from different stations and for different components (North, East and Up), transformed and expressed in ETRF2000. Legnica and Głogów are class I, the most precise category for the North and East component, the $\sigma$ error being in the range $1.0-1.4 \mathrm{~mm}$. For the vertical component (Up) they are class 2, which means an error in the range 3.5-5.0 $\mathrm{mm}$ (Araszkiewicz et al., 2009; Figurski et al., 2010).

Another GNSS station whose data was used for analysis is RUDNA, a station working for the commercial purposes of the KGHM company. Tests of accuracy of the station showed high precision of determined coordinates: $\sigma$ error of daily solutions for each horizontal component is $1.0 \mathrm{~mm}$ and for vertical one about $2.3 \mathrm{~mm}$. According to the meteorological service, weather conditions were steady during all analyzed time periods: there was no significant change in precipitation, temperature or air pressure.

\section{DISCUSSION OF RESULTS}

There were several stages in the analysis as suggested by successive figures. So, the daily positions of the stations are analyzed in terms of the linear distribution of particular coordinate changes (vertical and horizontal displacements), the azimuths of horizontal displacements and the spatial distribution of vertical displacements. The coordinates whose are of local system and the changes are related to the position recorded a matter of days before the tremors. A term "vector of displacement" used by the authors should be understood just as the position vector (horizontal or vertical) related to the position of a presumed starting point calculated for time point days before a particular event and position of a subsequent day. The same applies to the term "azimuths of displacement vector" (horizontal) which are not analyzed day by day but in relation to an assumed starting point in time. This "cumulative" approach is more practical and reliable due to the small length of daily vectors. The point is usually several days before a particular mining tremor but in the case of the RUDNA station according to the data, the starting moment is just two days before the only seismic event - March 19, 2013.

Firstly, distributions of horizontal and height changes are explored. During the both seismic events significant subsidence is observed. On February 9, 2010 the values of height changes over 2-3 days amounted to as much as $+14 \mathrm{~mm}$ (Głogów) but horizontal coordinates seem to be stable (Fig. 4). Although the horizontal position changes are not significant (less than the limitation error), their slight values certainly are not random. This can be confirmed by an analysis of the azimuths of the displacement vector. This movement becomes clear when outlined as a diagram of azimuths (Fig. 5). The magnitude of the horizontal displacement vector is 

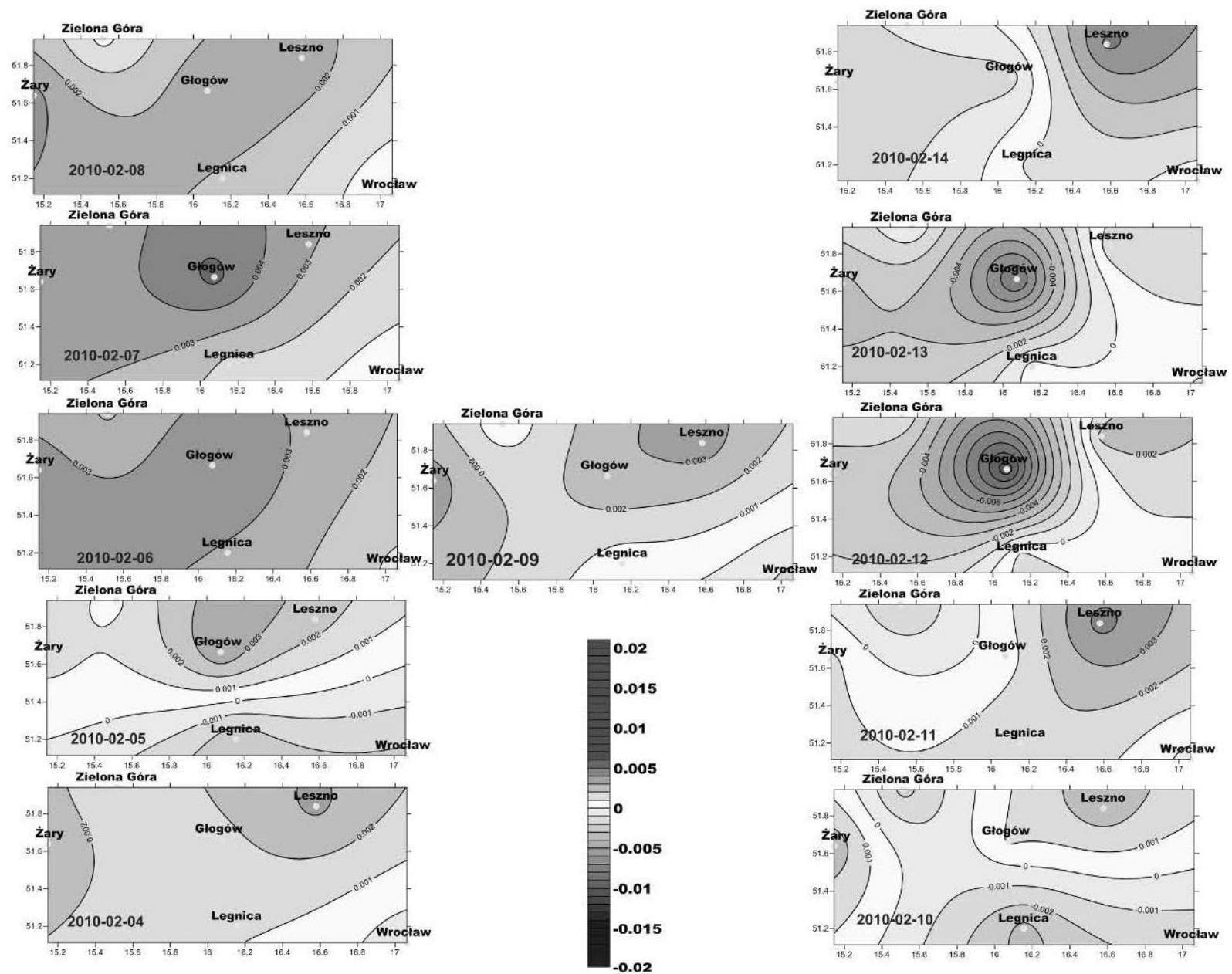

Fig. 6 Vertical displacements of ASG-EUPOS station located in the area of LGCD and in adjacent areas [m] day by day (the dates are on maps). The dates correspond to height changes observed in a particular day in relation to February 3, 2010.

small in comparing to the value of its error of their coordinate components. This means that the calculated azimuths of the displacements are affected by a high errors term, which could indicate a wide range of possible orientations. So the azimuth analysis is more illustrative than precise. Therefore there aren't error bars presented on graphs for this parameter. This outline (Fig. 5) shows the directions of the movements of the stations 5 days before and 5 days after the tremor. The chaotic changes in the displacement directions observed at the beginning of the period changed just after the moment of the seismic event and they turned into a regular movement toward to the south (compared with the initial position at the starting point of the time period). Although the values of the horizontal displacement rates were quite constant and the determined azimuths were with high error, changes in the azimuths do not seem to be accidental.

In short, within this period both stations (Legnica and Głogów) demonstrated slight vertical displacements (about $3 \mathrm{~mm}$ ) and very slight horizontal movement toward to the south (about $1 \mathrm{~mm} /$ day).
Another effect related to deformation during the analyzed time period is the spatial distribution of vertical displacements of the ASG-EUPOS stations adjacent to the area of the epicenter of the tremor of February 9, 2010 (Fig. 6). The presented outlines of the spatial distributions of the vertical daily displacements were calculated in relation to the starting moment i.e. February 3, 2010. The maps illustrate the process of the forming on uplift basin 2 days before the tremor with the center in the area of the Głogów station. Although the basin is not very regular and clear, the next deformation basin, the subsidence one, was formed 3 days after the tremor. That one is regular and strictly related to the area of the Głogów station as well. It should be pointed out that changes in coordinates determined as daily outcomes and the number of stations makes the evaluation of a precise model of basin development difficult.

A similar analysis was carried out for another time period when a seismic event occurred (the tremor from March $19^{\text {th }}$ 2013). In this case, data from the RUDNA permanent station was involved. The 

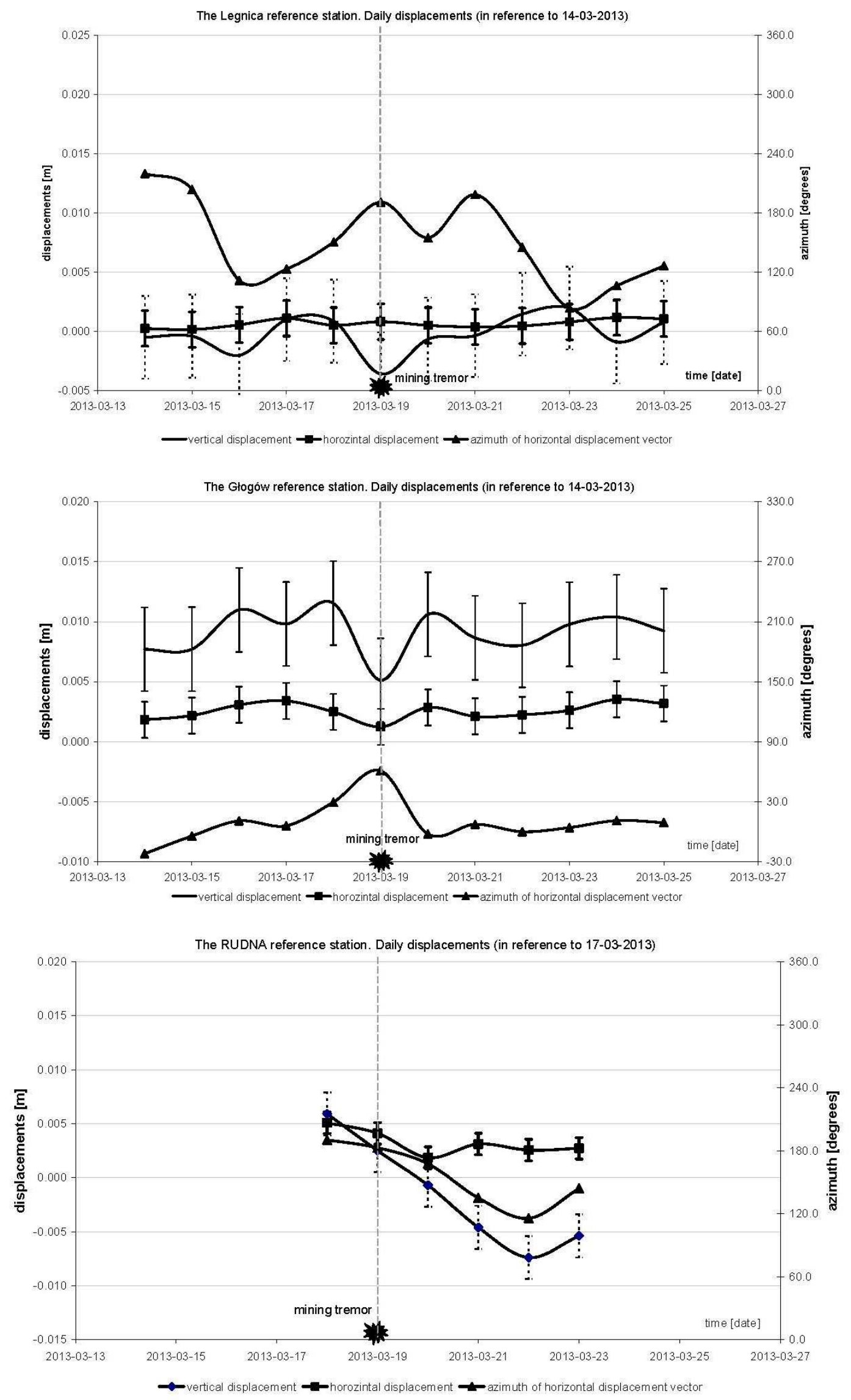

Fig. 7 Vertical displacements and horizontal displacements with the error bars and azimuth of displacement vectors of the analyzed permanent stations, March 2013. 


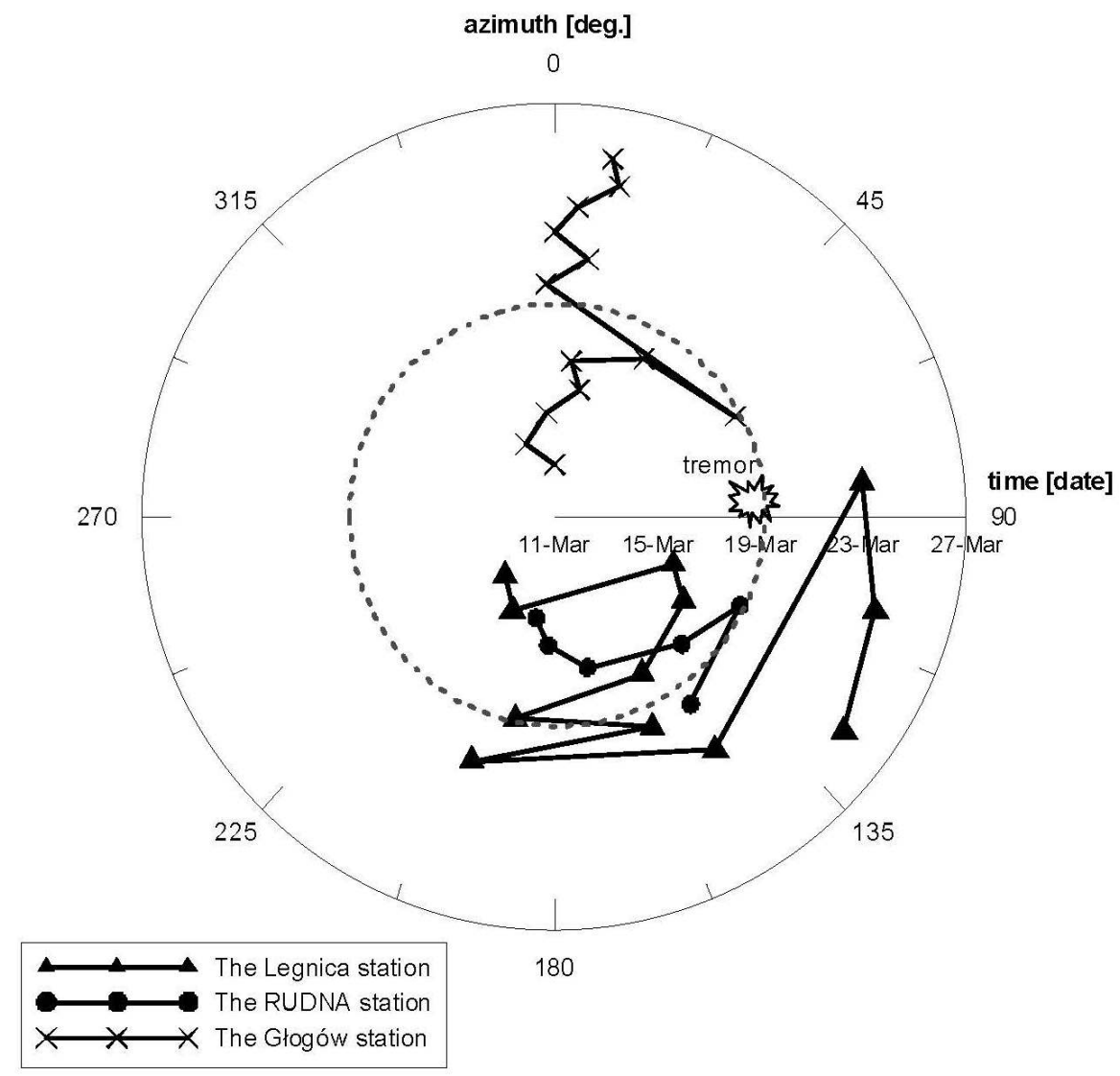

Fig. 8 Changes of azimuth of displacement vectors observed in the analyzed stations in March 2013.

distributions of coordinates and azimuth changes observed in 3 stations are presented in Figure 7. As during the period analyzed before there are no significant horizontal displacements of the Legnica station. Vertical displacements of this station are minimal - about $4 \mathrm{~mm}$ subsidence and there is no significant process of vertical displacement, and the subsidence seems to be accidental. Głogów, located closer to the tremor, demonstrated some different characteristics of displacements. Vertical displacements before the seismic event had a positive value (4-5 $\mathrm{mm}$ uplifts), but during the event subsidence of $6 \mathrm{~mm}$ was observed. Horizontal displacements corresponded to vertical movement, the slight increase in their rates started to stop 2 days before the event and after that they came back to values demonstrating a linear trend. The direction of this movement is depicted by the azimuths of the displacement vectors: the angle increase (southward direction) stopped on the day of the seismic event and after that a steady northward movement occurred (in comparison with the position of the starting point, i.e. 5 days before the event). The displacement process in the case of the RUDNA station, due to the observed distribution of the displacements and their values $-3 \mathrm{~mm} /$ day, is unambiguous. As mentioned before, there is only a week of observations to be analyzed. The distribution of vertical displacements demonstrated uplifts just before the seismic event and negative height changes from that moment for 4 days. Maximal subsidence amounted to $12 \mathrm{~mm}$ during that time period. Although the area of the station is affected by mining, the observed rates of displacements were much higher then the usual trend of station subsidence $(6 \mathrm{~mm} / \mathrm{yr})$. The temporal distribution of vertical displacements of this station is different from that of other cases. This station is located in the area of the epicenter so the expected effects of the tremors could be different.

Horizontal displacements followed the periodic trend of vertical displacements: just before the seismic event they were about $5 \mathrm{~mm}$ and after that they decreased for 1-2 days. Normal horizontal displacements of the station varied in the range of $10 \mathrm{~mm}$ during 4 years of observations. Noise-induced rapid oscillations were about $2 \mathrm{~mm}$ during the week of observations and no trend of horizontal displacement was observed. Azimuths changed nearly linearly from western to southern directions. A more comprehensive outline of azimuth changes is given in the diagram in Figure 8. According to changes in the displacement directions in Głogów and the RUDNA station, certain trends were disturbed on the day of the seismic event and the stations moved eastward. The same was true in the case of Legnica, although this station did not demonstrate a clear trend. 


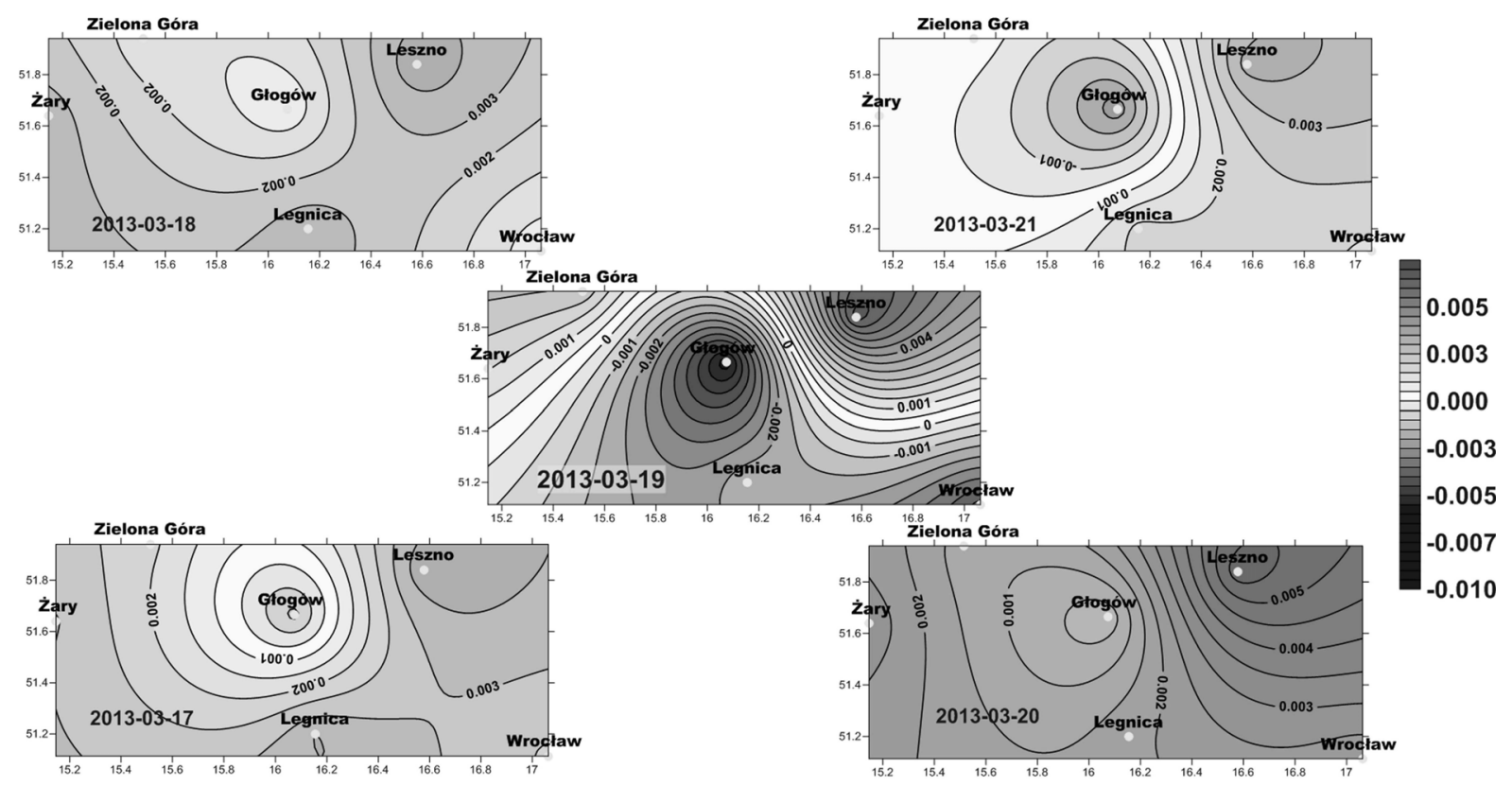

Fig. 9 Vertical displacements of ASG-EUPOS station located in the area of LGCD and in adjacent areas [m] day by day (the dates are on maps). The dates correspond to height changes observed in a particular day in relation to March 16, 2013.

The spatial distribution of vertical displacements (Fig. 9) which developed during the analyzed time period, the day by day changes analogous to those mentioned before, demonstrate the creation of a subsidence basin with its center in the Głogów area (the RUDNA station was not involved in this modeling). The most clear subsidence basin occurred on March $19^{\text {th }}$, on the day of the tremor. Other distributions of vertical displacements presented in the figure mostly have the same center but with much smaller maximal values of displacements.

So, during the second time period of the mining tremor those parameters which indicated deformations demonstrated a certain regularity as well. Although the displacements behaved somewhat differently during these episodes, there are some patterns here. In both cases significant subsidence occurred on the day of the seismic event or just after it, and all stations demonstrated some changes in the direction of horizontal movements after the tremors, even if the rates were very small.

\section{CONCLUSIONS}

This paper discusses displacements which occurred during mining induced tremors. Its aim is to combine insights into large seismic events with observations of the displacements of GNSS permanent stations on a regional scale. A time-frequency analysis of tremor impact on stations was excluded as a different research problem, and does not lead to an analytical solution of stress field spatial development. In this sense this work should be regarded as an initial probe to motivate further studies with a larger quantity of data.

Certain regularities in the observed displacements, which occurred during the analyzed time periods were demonstrated. Although the seismic events were triggered by mining, it is obvious that mining induced stress isn't created in isolation from the existing tectonic stress field. Interactions between both the stress fields and the fault-block structure of the area can affect those displacements which are induced by mining. The relation between the amplitude of vertical displacements observed in the GNSS stations and the distance from the epicenter of the tremors (especially for the tremor of March $19^{\text {th }}$ 2013, where displacements of the area of the epicenter were observed) does not appear accidental. This suggests a relation between displacement process and mining induced seismic tremor phenomena.

More case studies will be very valuable for modeling the possible effects of tectonic features.

\section{ACKNOWLEDGEMENTS}

The study presented here was carried out within statutory research project No. 11.11.150.195 at AGH University of Science and Technology, Faculty of Mining Surveying and Environmental Engineering, Department of Mining Areas Protection, Geoinformatics and Mining Surveying in Krakow. The work was supported by the Polish Ministry of Science and Higher Education and its grants for Scientific Research. 


\section{REFERENCES}

Araszkiewicz, A., Bogusz, J., Figurski, M., Kroszczyński, K. and Szafranek, K.: 2009, Report of 30 June, 2009 dealing with precise elaboration of observational data from permanent stations of ASG-EUPOS system. The Military Technical Academy, (in Polish). http://www.asgeupos.pl/webpg/graph/img/_syst_tests/ 20090630 WAT-CGS RaportASG-EUPOS.pdf

Bogusz, J., Figurski, M., Kontn, B. and Grzempowski, P.: 2012, Horizontal velocity field derived from EPN and ASG-EUPOS satellite data on the example of southwestern part of Poland. Acta Geodyn. Geomater., 9, No. 3(167), 349-357.

Butra, J. and Kudełko, J.: 2011, Rockburst hazard evaluation and prevention methods in Polish copper mines. Cuprum, 61, No. 4, 5-20.

Crowell, B.W., Bock Y. and Melgar, D.: 2012, Real-time inversion of GPS data for finite fault modeling and rapid hazard assessment. Geophys. Res. Lett., 39, L09305. DOI: 10.1029/2012GL051318

Dadlez, R., Marek, S. and Pokorski, J.: 2000, Geological map of the Poland without Cainozoic deposits. Wydaw. Kartograficzne Polskiej Agencji Ekologicznej, Warszawa.

Feigl, K.L.: 2002, Estimating earthquake source parameters from geodetic measurements. In: Lee, W.H.K., Kanamori, H., Jennings, P.C. and Kisslinger, C. (eds.): International Handbook of Earthquake \& Engineering Seismology, Part A. Academic Press, Amsterdam, 607-620.

Figurski, M., Szafranek, K., Bogusz, J. and Kamiński, P.: 2010, Investigation on stability of mountainous EUPOS sites' coordinates. Acta Geodyn. Geomater., 7, No. 3 (159), 263-274.

Hejmanowski, R., Malinowska, A., Stoch, T., Pluciński, P., Warchała, M. and Kosior, R.: 2008, New interpretation of GPS measurements results. Gospodarka Surowcami Mineralnymi. Instytut Gospodarki Surowcami Mineralnymi i Energią PAN, Krakow, 24, No. 3/1, 197-204.

Kijko, A. and Cichowicz, A.: 2006, Origin, intensity and damage potential of tectonic and mining seismic events. Investigation into the risks to miners, mines, and the public associated with large seismic events in gold mining districts. Report. Dept. of Minerals and Energy Rep. of South Africa. Appendix 4.2. Electronic document (acces: December 2014): http://www.csir.co.za/websource/pt10002/pdf files/ne ws/2006_dme/Seismic/DMEInvest_largeseismicevent svol2_\%20app4.2.pdf

Kłapciński, J.: 1964, Stratighraphy of the Zechstein in the areas of Lubin, Sieroszowice and Wschowa. Annales Sociedatis Geologorum Poloniae, 35. No 1-2, 77-135, (in Polish).

Kontny, B. and Bogusz, J.: 2012, Models of vertical movements of the Earth crust surface in the area of Poland derived from leveling and GNSS data. Acta Geodyn. Geomater., 9, No. 3(167), 331-337.

Kucha, H.: 1998, Plattnerite from Kupferschiefer, Poland, and its meaning for mineralizing conditions. Ann. Soc. Geol. Polon., 68, 279-285.

Laskowski, M., Samokar, Z. and Wróbel, J.: 2014, The effect of dynamic and regional phenomena on mining workings an terrain surface on the example of rock burst occured on 19 March 2013 in G-3/4 field of the $\mathrm{O} / \mathrm{ZG}$ Rudna mine. Zeszyty Naukowe Instytutu
Gospodarki Surowcami Mineralnymi i Energią PAN Kraków, No. 86, 83-96, (in Polish, English abstract).

Lizurek, G., Rudziński, Ł. and Lesiewicz, B.: 2015, Mining induced seismic event on an inactive fault. Acta Geophysica. 63, No. 1, 176-200. DOI: 10.2478/s11600-014-0249-y

Melgar, D., Bock, Y. and Crowell B.W.: 2012, Real-time centroid moment tensor determination for large earthquakes from local and regional displacement records. Geophys. J. Int., 188, No. 2, 703-718. DOI: $10.1111 /$ j.1365-246X.2011.05297.x

Oberc, J. and Tomaszewski, J.: 1963, Some aspects of straatygraphy and subdivision of Zechstein in the Wroclaw monocline. Przegląd Geologiczny, 11, No. 12, 505-509, (in Polish).

Orlecka-Sikora, B., Papadimitriou, E.E. and Kwiatek, G.: 2009, A Study of the interaction among mininginduced seismic events in the Legnica-Głogów Copper District, Poland. Acta Geophysica, 57, No. 2, 413-434. DOI: 10.2478/s11600-008-0085-z

Popiołek, E., Ostrowski, J., Czaja, J. and Mazur, J.: 2001, The impact of a strong mining tremor on the subsidence of the area surface in the Legnica-Glogow Copper Area. 10th FIG Int. Symposium on Deformation Measurements. Orange - California USA, 19-22 March 2001.

Preidl, M.: 1967, Tectonic structure of the Lubina and Sieroszowice area. Przegląd Geologiczny, 15, No. 6, 257-260, (in Polish).

Salski, W.: 1996, The tectonics of the deposit. In: Monografia KGHM Polska, Miedź, S.A. and Piestrzyński, A. (eds.). Pub. Profil, Kraków, (in Polish).

Swanson, P. L. and Sines, C. D.: 1991, Characteristics of mining-induced seismicity and rock bursting in a deep hard-rock mine. Report of Investigations, US. Dept. of the Interior, Bureau of Mines, No. 9393, 12 pp.

Wanior, J.: 1983, Method of prognosis of tremors or rock bursts on the base of results of geodetic measurements on the example of mining carried in the protection pillar of Bytom city. Doctoral dissertation. Kraków: UST AGH in Krakow. Not published.

Węglarczyk, S. and Lasocki, S.: 2009, Studies of short and long memory in mining-induced seismic processes. Acta Geophysica, 57, No. 3, 696-715. DOI: $10.2478 / \mathrm{s} 11600-009-0021-\mathrm{x}$

\section{Electronic documents:}

Information No 2/2010 śm./EW. Mining Authority of Poland. Electronic document:

http://www.wug.gov.pl/index.php?statystyki/9_02_2010 (access 10 January 2015).

Information No 17/2013/EW. Mining Authority of Poland. Electronic document:

http://www.wug.gov.pl/index.php?statystyki/19_03_2013 (access 10 January 2015). 